\title{
Heavy Metal Concentration in Ambient Air University Campus Located Near the Industrial Area
}

\author{
Radin Maya Saphira bte Radin Mohamed ${ }^{1, a}$, Noor Maisara bte Jais ${ }^{2, b}$, \\ Farah Hanim Bt. Che Aziz ${ }^{3, c}$, Amir Hashim bin Mohd. Kassim ${ }^{4, d}$ \\ and Norzila Othman ${ }^{5, \mathrm{e}}$ \\ ${ }^{1,2,3,4,5}$ Faculty of Civil and Environmental Engineering, \\ Universiti Tun Hussien Onn Malaysia, \\ Locked Bag 101, 86400 Parit Raja, Batu Pahat.Johor, Malaysia \\ amaya@uthm.edu.my, bnoormaisarajais@gmail.com, 'frhhanim@yahoo.com, \\ damir@uthm.edu.myl, enorzila@uthm.edu.my
}

Keywords: heavy metals, air quality, UTHM, ICP-MS, industry

\begin{abstract}
This study aims to measure the concentration of heavy metals of concern Lead $(\mathrm{Pb})$, Copper $(\mathrm{Cu})$, Chromium $(\mathrm{Cr})$, Cadmium $(\mathrm{Cd})$ and Nickel $(\mathrm{Ni})$ at three university campus buildings which was situated adjacent to an industrial district. Heavy metals particulates were sampled from the $\mathrm{PM}_{10}$ sampling device (Met One Instrument) in 24 hours sampling between lecture and holiday periods. Determination of heavy metals concentrations were conducted using Inductively Coupled Plasma - Mass Spectrometry (ICP-MS) after the filter papers were digested with mixture of nitric acid $\left(\mathrm{HNO}_{3}\right)$ and sulphuric acid $\left(\mathrm{H}_{2} \mathrm{SO}_{4}\right)$. These heavy metal concentrations were compared to the Standard Concentration on Air such as World Health Organization Health (WHO), Ambient Air Quality Criteria Act 1994 (AAQC), National Environment Protection Council (NEPS) and also Texas Commission on Environmental Quality (TCEQ). The comparison with Standard Concentration of Air shows that $\mathrm{Cd}$ and $\mathrm{Cu}$ have low concentrations $0.0033 \pm 0.0018 \mu \mathrm{g} / \mathrm{m}^{3}$ and $0.0894 \pm 0.0614 \mu \mathrm{g} / \mathrm{m}^{3}$ while $\mathrm{Cr}$ and $\mathrm{Ni}$ have high concentrations of $0.1882 \pm 0.0535 \mu \mathrm{g} / \mathrm{m}^{3}$ and $0.1278 \pm 0.0323 \mu \mathrm{g} / \mathrm{m}^{3}$ respectively. The $\mathrm{Pb}$ gives irregular result and high standard deviation of $2.0410 \pm 3.4999 \mu \mathrm{g} / \mathrm{m}^{3}$. This finding produces significant contribution to some knowledge of the level of heavy metals in the study area. It identifies research needs and suggests potential approaches to addressing outstanding problems.
\end{abstract}

\section{Introduction}

Semiconductor industry contributes greatly for Malaysia economy which is $26.94 \%$ for manufacturing output such as chemical substance manufacturing plants, car manufacturing, wood processing, food and beverages, $48.7 \%$ for exports and $32.5 \%$ for employment which all these factories are capable to provide employment opportunities to many people [1]. The rapid growth of the population has shown it contributes to the increase of air pollution. High density in population cause intensive anthropogenic activities, where it will produce the emission of heavy metal into the ambient air and to its surrounding that influence considerably on human health $[2,3]$.

Indeed, air pollution is a must to be worried for, because some previous research show that the concentrations of heavy metal in ambient air are higher than the allowable rate. It shown that the $\mathrm{Pb}$ concentration are $0.103 \mu \mathrm{g} / \mathrm{m}^{3}$ in Howard University, Washington; Shangai - Nanjing Expressway and Balakong shows that the main pollutants are $\mathrm{Zn}$ and $\mathrm{Pb}$ while in Spata, that the concentration of $\mathrm{Cd}, \mathrm{Pb}$ and $\mathrm{Ni}$ are $1.07 \mu \mathrm{g} / \mathrm{m}^{3}, 8.95 \mu \mathrm{g} / \mathrm{m}^{3}$ and $45.1 \mu \mathrm{g} / \mathrm{m}^{3}$ respectively [4,5,6,]. In UTHM campus, Mohamed et al. [7] has assesed the levels of $\mathrm{Pb}, \mathrm{Cu}, \mathrm{Cr}, \mathrm{Cd}, \mathrm{Ni}, \mathrm{Zn}$ in ambient air and was found the concentrations of $\mathrm{Cr}, \mathrm{Cd}$, and $\mathrm{Ni}$ exceeded the standard concentrations which were 0.0100 $\mu \mathrm{g} / \mathrm{m}^{3}, 0.0050 \mu \mathrm{g} / \mathrm{m}^{3}$ and $0.0150 \mu \mathrm{g} / \mathrm{m}^{3}$, respectively. Therefore, the aim of this study is to provide the levels of heavy metals concentration through continuos monitoring in UTHM campus which the location is in industrial zone, and has been the main concern to the public health. 


\section{Background of the Study Site}

The Universiti Tun Hussein Onn Malaysia (UTHM) is located in Batu Pahat, Johor, Malaysia $\left(1^{\circ} 51^{\prime} 11^{\prime \prime} \mathrm{N} / 103^{\circ} 4^{\prime} 48^{\prime \prime} \mathrm{W}\right)$ and has a student population of approximately 12,800 (data on July 2014). Due to its proximity to a nearby industrial park (activities include data centers, electrical appliances manufacturing, wood processing plants, corrugated carton maker and packaging facilities) and its location in a hilly terrain (Fig. 1), events of air pollution and its persistence, especially that of heavy metals is of particular concern to the health and well-being of the student and faculty population.

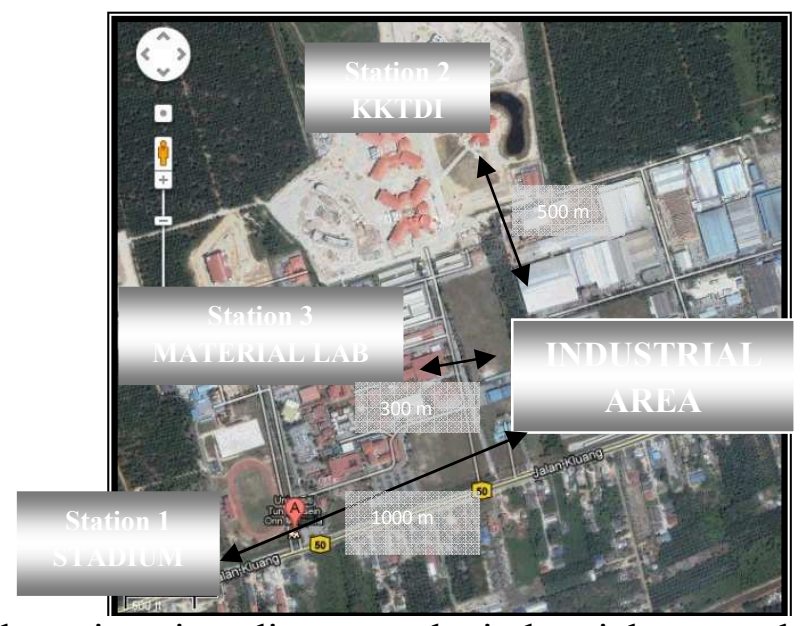

Figure 1: Location of the university adjacent to the industrial area and the distance of the sampling station from the industrial area (retrieved on 21 December, 2013, googlemap.com)

\section{Implication the Usage of Heavy Metals in Industry}

Environment especially air is often being a location to discharge waste generated by the industrial manufacturing process. Wood processing industries rely on heavy metals, where Copper Chrome Arsenate (CCA) being used to treat and preserve wood from natural degradation by termite activity, crustaceans (crabs), mollusks (snails) and bacteria [8]. The semiconductor industry uses $\mathrm{Cd}, \mathrm{Cu}$ and $\mathrm{Pb}$; plastic industry, dye substances and ink pigments and chemical manufacturing uses $\mathrm{Pb}, \mathrm{Cu}, \mathrm{Cd}, \mathrm{Ni}$ and $\mathrm{Cr}$ which for dye substances, heavy metals are needed to produce color such as orange $(\mathrm{Cd})$, black $(\mathrm{Ni})$, and green $(\mathrm{Cr})$ while $\mathrm{Cd}, \mathrm{Cr}$ and $\mathrm{Pb}$ are required in processing organic and inorganic chemical $[8,9]$. Nevertheless, this element is easy to be absorbed by water and vapor whereby they can be harmful to human health and aquatic life. Exposure of heavy metals can cause major health effect such as acute, chronic or temporary effect, throat irritation coughing, chest pain, and general discomfort are some of temporary effect from the exposure of heavy metals $[9,10]$.

\section{Air Quality Standard}

In present day, whether in the developed or developing country, the air pollution becomes more critical. Department of Environment (DOE) is the government agency involved in the regulation of air pollution in Malaysia. Somehow, Malaysia does not have its own standard set for heavy metals concentration in the ambient air, but the references such as Ambient Air Quality Criteria Act 1994 (AAQC), World Organization Health (WHO), Texas Commission on Environmental Quality (TCEQ), National Environment Protection Council (NEPS) are being used as show in Table 1.

Table 1: Heavy Metals with their Standard Concentration on Air

\begin{tabular}{ccc}
\hline \hline \multirow{2}{*}{ Heavy Metal } & \multicolumn{2}{c}{ Standard Concentration } \\
\cline { 2 - 3 } & {$\left[\mu \mathrm{g} / \mathrm{m}^{3}\right]$} & References \\
$\mathrm{nd}$ & 0.005 & WHO, AAQC \\
$\mathrm{Pb}$ & 0.5 & NEPC, AAQC \\
$\mathrm{Cr}$ & 0.01 & TCEQ \\
$\mathrm{Ni}$ & 0.015 & TCEQ \\
$\mathrm{Cu}$ & 1.0 & TCEQ \\
\hline \hline
\end{tabular}




\section{Methodology}

Preparations of the samples were started by trapping heavy metals on the filter paper by using ESampler Particulate Matter (PM10) Collector. Data was recorded in the data logger for 24 hours of the sampling period. Three sampling stations were selected based on distances from the industrial district (Fig. 1). After collection, the digestion by hot extraction acid was performed with addition of $10 \mathrm{ml}$ of concentrated $\mathrm{H}_{2} \mathrm{SO}_{4}$ and $5 \mathrm{ml}$ of $\mathrm{HNO}_{3}$. Subsequently, it was placed on a hot plate for 2 hours in $60-70^{\circ} \mathrm{C}$ and keep the sample at $4^{\circ} \mathrm{C}$ [11]. The samples were diluted to quantify the heavy metals by using Inductively Coupled Plasma-Mass Spectrometry (ICP-MS). The data of heavy metals concentration from the air quality sample in UTHM main campus were analyzed and compared to the Standard Heavy Metals Concentration on Air. Relationship between metrological factor and concentration of heavy metals were tested by using Pearson Correlation Coefficient, $(p<0.05)$ to determine if there were any significant influence between them.

\section{Results and Discussion}

Table 2 presents a summary of the comparison of the heavy metals concentration average and standard deviation at three stations during the holidays and lecture days as compared with the Standard Concentration on Ambient Air.

Table 2: Comparison of Average Concentration of Heavy Metals in Three Stations during Holidays and Lectures Days with their Standard Deviations $(n=3)$

\begin{tabular}{|c|c|c|c|c|c|c|c|}
\hline \multirow{2}{*}{$\begin{array}{l}\text { Heavy } \\
\text { Metal }\end{array}$} & \multirow{2}{*}{$\begin{array}{c}\text { Standard } \\
\text { Concentration }\end{array}$} & \multicolumn{2}{|c|}{ Station 1 (Stadium) } & \multicolumn{2}{|c|}{ Station 2 (KKTDI) } & \multicolumn{2}{|c|}{$\begin{array}{c}\text { Station } 3 \\
\text { (Material Laboratory) }\end{array}$} \\
\hline & & Holidays & $\begin{array}{c}\text { Lectures } \\
\text { Days }\end{array}$ & Holidays & $\begin{array}{c}\text { Lectures } \\
\text { Days }\end{array}$ & Holidays & $\begin{array}{c}\text { Lectures } \\
\text { Days }\end{array}$ \\
\hline \multirow{4}{*}{$\mathrm{Cd}$} & \multirow{3}{*}{0.0050} & 0.0033 & 0.0017 & 0.0045 & 0.0042 & 0.0049 & \multirow[t]{3}{*}{, } \\
\hline & & \pm & \pm & \pm & \pm & \pm & \\
\hline & & 0.0018 & 0.0002 & 0.0038 & 0.0026 & 0.0033 & \\
\hline & \multirow{4}{*}{0.0100} & 0.1882 & 0.1168 & 0.2726 & 0.1830 & 0.3865 & \multirow{3}{*}{-} \\
\hline \multirow[t]{3}{*}{$\mathrm{Cr}$} & & \pm & \pm & \pm & \pm & \pm & \\
\hline & & 0.0535 & 0.0614 & 0.1522 & 0.1098 & 0.3686 & \\
\hline & & 0.0894 & 0.0359 & 0.0973 & 0.2066 & 0.0775 & \multirow{4}{*}{-} \\
\hline \multirow{3}{*}{$\mathrm{Cu}$} & \multirow[t]{3}{*}{1.0000} & \pm & \pm & \pm & \pm & \pm & \\
\hline & & 0.0614 & 0.0152 & 0.0637 & 0.0532 & 0.0532 & \\
\hline & & 2.0410 & 0.1036 & 0.0293 & 1.3791 & 1.0724 & \\
\hline \multirow[t]{3}{*}{$\mathrm{Pb}$} & \multirow[t]{3}{*}{0.5000} & \pm & \pm & \pm & \pm & \pm & \multirow[t]{2}{*}{ - } \\
\hline & & 3.4999 & 0.1388 & 0.0222 & 2.3302 & 0.6438 & \\
\hline & & 0.1278 & 0.0680 & 0.1538 & 0.1268 & 0.2628 & \multirow{3}{*}{-} \\
\hline \multirow[t]{2}{*}{$\mathrm{Ni}$} & \multirow[t]{2}{*}{0.0150} & \pm & \pm & \pm & \pm & \pm & \\
\hline & & 0.0323 & 0.0225 & 0.1060 & 0.0792 & 0.2361 & \\
\hline
\end{tabular}

[Unit of heavy metal $\mu \mathrm{g} / \mathrm{m}$ ]

A bar chart of comparisons on the average heavy metals concentration at the Station 1 (Stadium), Station 2 (Kolej Kediaman Tun Dr Ismail) and Station 3 (Material Laboratory) during the holidays and lectures days are illustrated on Fig. 2. which were compared to four standard references; WHO, AAQC, NEPS and TCEQ as documented in Table 2. It can be noted that the three stations on UTHM main campus is exposed to the existence of heavy metals but no information during the lecture days at the Material Laboratory because of damage the equipment E-Sampler Particulate Matter (PM10) Collector.

In Fig. 2, it shows that the highest concentration of $\mathrm{Pb}$ was at the Station 1 (Stadium) with the value of $2.0410 \pm 3.4999 \mu \mathrm{g} / \mathrm{m}^{3}$. The high volume of traffic during the period might act as a source of $\mathrm{Pb}$ emission that comes from the vehicles that used leaded gasoline fumes [4]. Detected $\mathrm{Pb}$ concentration were between $0.21 \pm 0.62 \mu \mathrm{g} / \mathrm{m}^{3}$ and it was much lower compared to the detected $\mathrm{Pb}$ at Station 1 (Stadium). The large gap between standard deviation and the average of $\mathrm{Pb}$ concentration was due to the occurrence of rain in the afternoon of the second day sampling while 
hot weather at other times during the sampling. The concentration of $\mathrm{Pb}$ at Stadium station was compared to the standard sets that were the AAQC and NEPC. Concentration of $\mathrm{Pb}$ at Station 1 (Stadium) did not comply with the standard in ambient air as $3.4999 \mu \mathrm{g} / \mathrm{m}^{3}$ was higher than 0.5 $\mu \mathrm{g} / \mathrm{m}^{3}$.

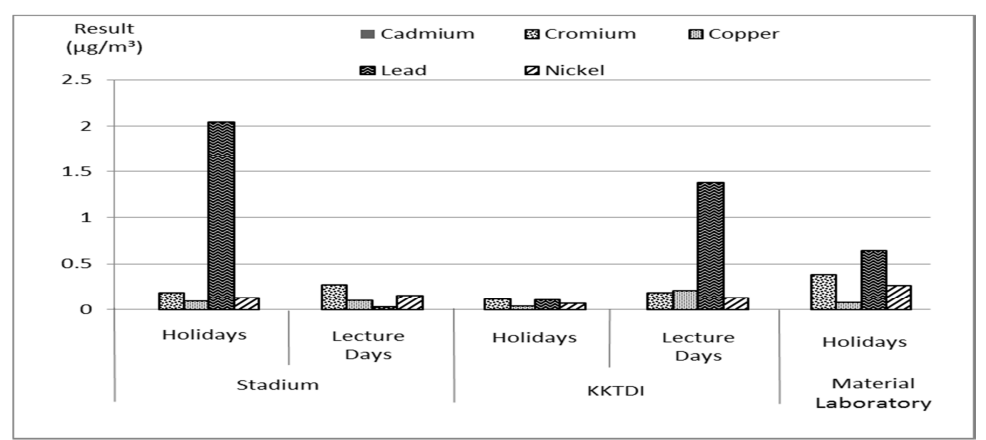

Figure 2 : Comparison of Heavy Metals Concentration in Three Station during Holidays and Lectures Days

The concentration of $\mathrm{Cr}$ was found the second highest heavy metals in UTHM ambient air. $\mathrm{Cr}$ level at Station 3 (Material Laboratory) shows a high concentration of $0.3865 \pm 0.3686 \mu \mathrm{g} / \mathrm{m}^{3} \mathrm{during}$ the holiday. It was even higher when compared with the TCEQ which stated the allowable $\mathrm{Cr}$ concentration in air was $0.01 \mu \mathrm{g} / \mathrm{m}^{3}$. However, this concentration was lower when compared to the concentration at industrial area which found as major contribution of $\mathrm{Cr}$ concentration such as in Balakong, Malaysia which have the high congested traffic was detected $2600 \pm 300 \mu \mathrm{g} / \mathrm{m}^{3}$ [5]. Even though there was a similarity in case of industrial location, the type and number of factories were considered as a factor.

The Ni concentration was detected high in the Station 3 (Material Laboratory) was 0.2628 $\mu \mathrm{g} / \mathrm{m}^{3}$. Both station, Hissar Road and Material Laboratory turn up to have a slight unlike in value of $\mathrm{Ni}$ concentration as in the Station 3 where $0.54 \mu \mathrm{g} / \mathrm{m}^{3}$ which located adjacent to the industrial area [12]. In the Station 3 (Material Laboratory), the concentration of both heavy metals $\mathrm{Cr}$ and Ni were highest compared to the other stations. Meteorological factors such as temperature $(p=0.001)$ and humidity ( $p=0.002)$ were found significant in Table 3 and both situations exceeding the standards concentration which is set by the TCEQ for $\mathrm{Cr}$ and Ni which are $0.01 \mu \mathrm{g} / \mathrm{m}^{3}$ and $0.015 \mu \mathrm{g} / \mathrm{m}^{3}$ in the ambient air. The high relative humidity which achieved $51 \%$ because of long heavy rain occurs the three days of sampling conducted.

Table 3: Significant values of $\mathrm{PM}_{10}$ adapted from the E-Sampler device and the influence of the meteorological factors

\begin{tabular}{|c|c|c|c|}
\hline \multirow[t]{2}{*}{ Station } & \multirow{2}{*}{$\begin{array}{l}\text { Meteorology } \\
\text { Factors }\end{array}$} & \multicolumn{2}{|c|}{ P value } \\
\hline & & Lecture & Holiday \\
\hline \multirow[t]{4}{*}{ S Station 1 (Stadium) } & Temperature & & 0.011 \\
\hline & Humidity & 0.002 & - \\
\hline & Wind speed & 0.005 & - \\
\hline & Wind direction & - & - \\
\hline \multirow[t]{4}{*}{ Station 2 (KKTDI) } & Temperature & 0.005 & - \\
\hline & Humidity & - & - \\
\hline & Wind speed & 0 & - \\
\hline & Wind direction & - & 0.001 \\
\hline Station 3 (Material & Temperature & - & 0.001 \\
\hline \multirow[t]{3}{*}{ Laboratory) } & Humidity & - & 0.002 \\
\hline & Wind speed & $\mathrm{P}=0.039$ & $\mathrm{P}=0$ \\
\hline & Wind direction & - & - \\
\hline
\end{tabular}




\section{Conclusion}

Based on the results, it is found that the concentrations of selected heavy metals are high even with some heavy metals such as $\mathrm{Cr}$ and $\mathrm{Ni}$ which exceed with the standard concentration which are $0.0100 \mu \mathrm{g} / \mathrm{m}^{3}$ for $\mathrm{Cr}$ and $0.0150 \mu \mathrm{g} / \mathrm{m}^{3}$ for Ni. Contrary to that results, the $\mathrm{Cu}$ and $\mathrm{Cd}$ have a lower concentration and still adequate compared to the standard which are $1.0000 \mu \mathrm{g} / \mathrm{m}^{3}$ and 0.0050 $\mu \mathrm{g} / \mathrm{m}^{3}$. However, the $\mathrm{Pb}$ concentration are not uniformed.

\section{References}

[1] Information on http://www.mida.gov.my/env3/index.php?page=ee. Malaysia Investment Development Authority (MIDA).

[2] Xi, C., Xinghui, X., Ye, Z., Ping, Z., Heavy metal concentration in roadside soils and correlation with urban traffic in Beijing, China. J. Hazardous Materials. (2010).

[3] Cropper, M., Griffiths, C., The Interaction of Population Growth and Environmental Quality. The American Economic Review. 84 (1994) 250-254.

[4] Melaku, S., Morris, V., Raghavan, D., Hosten, C., Seasonal Variation of Heavy Metals in Ambient Air and Precipition at a Single in Washington, DC. Envi. Pollution. 155(1) (2008) 88-98.

[5] Zhao, Y., Zhao, C., Concentration and Distribution Analysis of Heavy Metals in Total Suspended Particulates alng Shanghai - Nanjing Expressway. Procedia Envi. Sci. 13 (2012) 137 141.

[6] Sulaiman, N., Abdullah, M., Chieu, P.L.P., Concentration and Composition of PM10 in Outdoor and Indoor Air in Industrial Area of Balakong Selangor, Malaysia. Sains Malaysiana. 34(2) (2005) 43 - 47.

[7] Mohamed, R.M.S.R., Aziz, F.H.B.C., Kassim, A.H.M., An assessment of selected heavy metal concentrations $(\mathrm{Pb}, \mathrm{Cu}, \mathrm{Cr}, \mathrm{Cd}, \mathrm{Ni}, \mathrm{Zn})$ in university campus located in industrial area. ARPN Journal of Engineering and Applied Science, 9 (12) (2014) 2724-2730.

[8] Wood Processing Industry Greenomics Indonesia October 2004.

[9] Schischke, K., Stutz, M., Ruelle, P., Griese, H., Reichl, H., Life Cycle Inventory Analysis and Identification of Environmentally Significant Aspects in Semiconductor Manufacturing. Proceedings of the 2001 IEEE International Symposium on Sustainability and the Environment. (2001) 145-150.

[10] Karim, S., Penspesiesan Logam Berat dalam air sisa campuran Industri di Sistem Perparitan Tertutup, Zon Perindustrian Prai 1 dan 2, Pulau Pinang (2007)

[11] Vijayanand, C., Rajaguru, P., Kalaiselvi, K., Selvam, K. P., Palanivel, M., Assessment of heavy metal contents in the ambient air of the Coimbatore city, Tamilnadu, India. J Hazardous Materials. 160 (2008) $548-553$.

[12] Dalal, P., Chaudhry, D., Shukla, V. Analysis of Heavy Metals Concentration in Ambient Air and in Human Population of Rohtak, India. J. Envi. Bio. (2009). 